\title{
Planktic Foraminiferal Biostratigraphy of the Upper Part of the Damlouk Member, Ratga Formation, Western Desert, Iraq
}

\author{
Imad M. Ghafor \\ Dept. Of Geology/ College of Science \\ University of Sulaimani
}

\author{
Basim A. Al-Qayim \\ Dept. of Petroleum Engineering \\ Komar University of Sci. and Tech.
}

(Received 24/6/2021 ， Accepted 5/10/2021)

\begin{abstract}
The basinal part of the Damlouk Member upper sedimentary cycle of the Ratga Formation exposed in the Qaim area of the Iraqi western desert is examined. The studied section consists of marlstone, marly and phosphatic limestone, and planktic foraminiferarich limestone beds. Detailed study of the planktic foraminiferal assemblages of these rocks revealed the occurrences of (30) species belonging to (11) genera. The stratigraphic distribution of these species permits the recognition of three biozones. These are from the lower to upper part of the section: - Acarinina bullbrooki Zone, (Middle Lutetian), Morozovelloides lehneri Zone, (Late Lutetian), Globigerinatheca semiinvoluta Hantkenina alabamensis Zone, (Early Bartonian). These zones indicate that the studied section of the Ratga Formation (Damlouk Member) is of Middle-Late Lutetian to Early Bartonian age. These biozones are correlated with different local and regional studies.

Key words: Planktic foraminifera; biostratigraphy; Eocene; Ratga Formation; Iraq

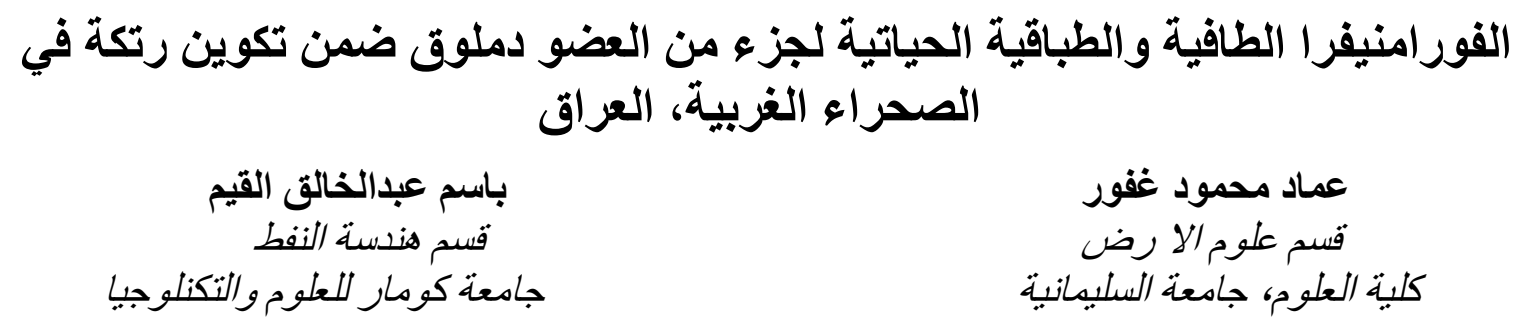

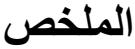

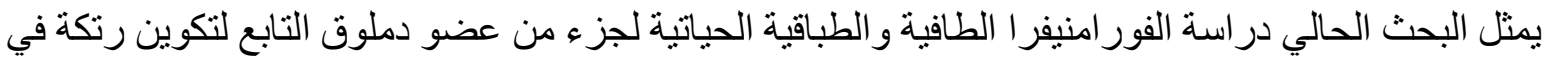

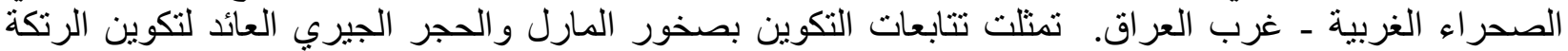

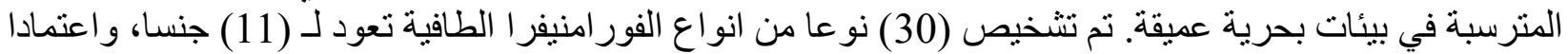

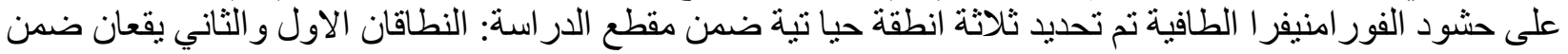

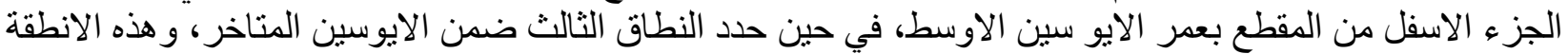
الحياتية هي من الاقدم في الاسفل الى الاحدث في الاعلى كالاتي: -
\end{abstract} Acarinina bullbrooki Zone (Middle Lutetian) Morozovelloides lehneri Zone (Late Lutetian) Globigerinatheka semiinvoluta -Hantkenina alabamensis Zone (Early Bartonian) الكلمات: الفور امنيفر ا الطافية، الطباقية الحياتية، الأيوسين، تكوين رتكة، العر اق. 


\section{INTRODUCTION}

The Paleogene succession of the Western Desert of Iraq is an interesting sequence for two reasons; it includes the economically attractive phosphatic horizons of Iraq. The second reason is due to the stable tectonic situation of the area, which will preserve the Paleogene sequence as compared to the Arabian active plate margin of NE Iraq. Based on that interest, further study and understanding the origin and the history of this sequence are needed. This work aims to contribute to the revision of the chronostratigraphic framework of the Paleogene successions in the Western Desert. The stratigraphic description of the Paleogene sequence of the Western Desert is subject to active and detailed works by the geologists of the Geological Survey of Iraq to evaluate its potential mineral resources including phosphates and Uranium (Al- Mubarak and Ameen 1983; Hagopian 1979; Karim and Al-Bassam, 1997). These efforts followed the detailed work of (Bellen et al., 1959) who had established the early stratigraphic subdivisions of the area. Followed by the work of (Al-Naqib, 1967) who had reviewed the general geology of the Western Desert. The work of (Hagopian, 1979) is considered an important stratigraphic contribution. He subdivided the Eocene Dammam Formation exposed at the edge of the western desert into five lithologic units based on lithostratigraphic characteristics. Extensive works of teams follow this attempt from the geological survey in detail to study the stratigraphic relations of the Paleogene phosphatic rich strata. The Eocene strata of the study area are considered now to be included in the Ratga Formation, which is introduced informally for the first time by (Jassim et al., 1984; and Al-Bassam et al., 1986). Karim and Al-Bassam (1997) gave the stratigraphic formal and detailed description of the Ratga Formation type section, which is subdivided into three lithologic members and they are from bottom to top as follows: Swab, Damlouk, and Mugur Members. Outcrops of these members are distributed along valleys such as Swab, Akashat, and Ratga, which are drained down towards the Ga'ara Depression to the southeast. The selected section of the Damlouk Member for this study is located along Wadi Akashat at the northwestern part of the Iraqi Western Desert, about 80 kilometers north of Rutba Town. The investigated area is called the Akashat area, which runs between $40^{\circ} 00^{\prime}$ and $40^{\circ} 15^{\prime}$ Long., and $34^{\circ} 00^{\prime}$ and $33^{\circ} 45^{\prime}$ Lat. (Fig. 1).

\section{LITHOSTRATIGRAPHY}

Karim and Al-Bassam (1997) formally describe the Ratga Formation of Lower-Upper Eocene age with details. It is geographically cropped out and distributed in the Western Desert with a thickness range between $200-220 \mathrm{~m}$. This unit consists mainly of cyclic alternations of marl and marly limestone. The lower basinal unit of the pelagic marly limestone is often recognized as partly phosphatic, intensively recrystallized to chalky limestone with silicification as chert horizons and nodules. The upper unit is composed of shallow marine Nummulitic limestone variably intermixed with shelly bioclastic limestone. It is subdivided into three lithologic members from the bottom to the top: Swab, Damlouk, and Mugur Members (Fig. 2). 
51 Planktic Foraminiferal Biostratigraphy of the Upper Part of the Damlouk Member

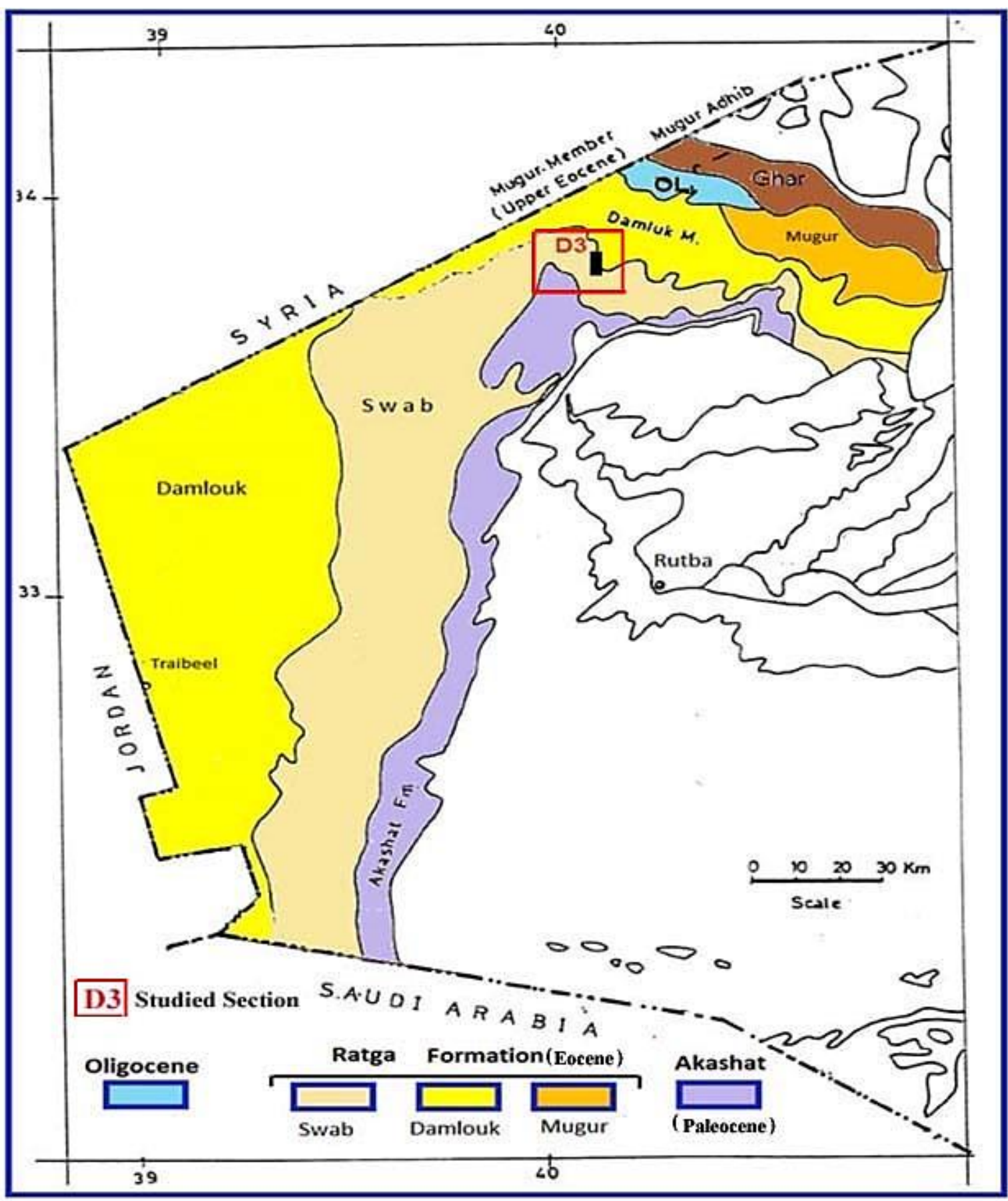

Fig. 1: Detailed geological map of the Ratga Formation at the Western Desert showing outcrop of its members and the location of the studied section (D3). (From Karim and Al-Bassam, 1997). 


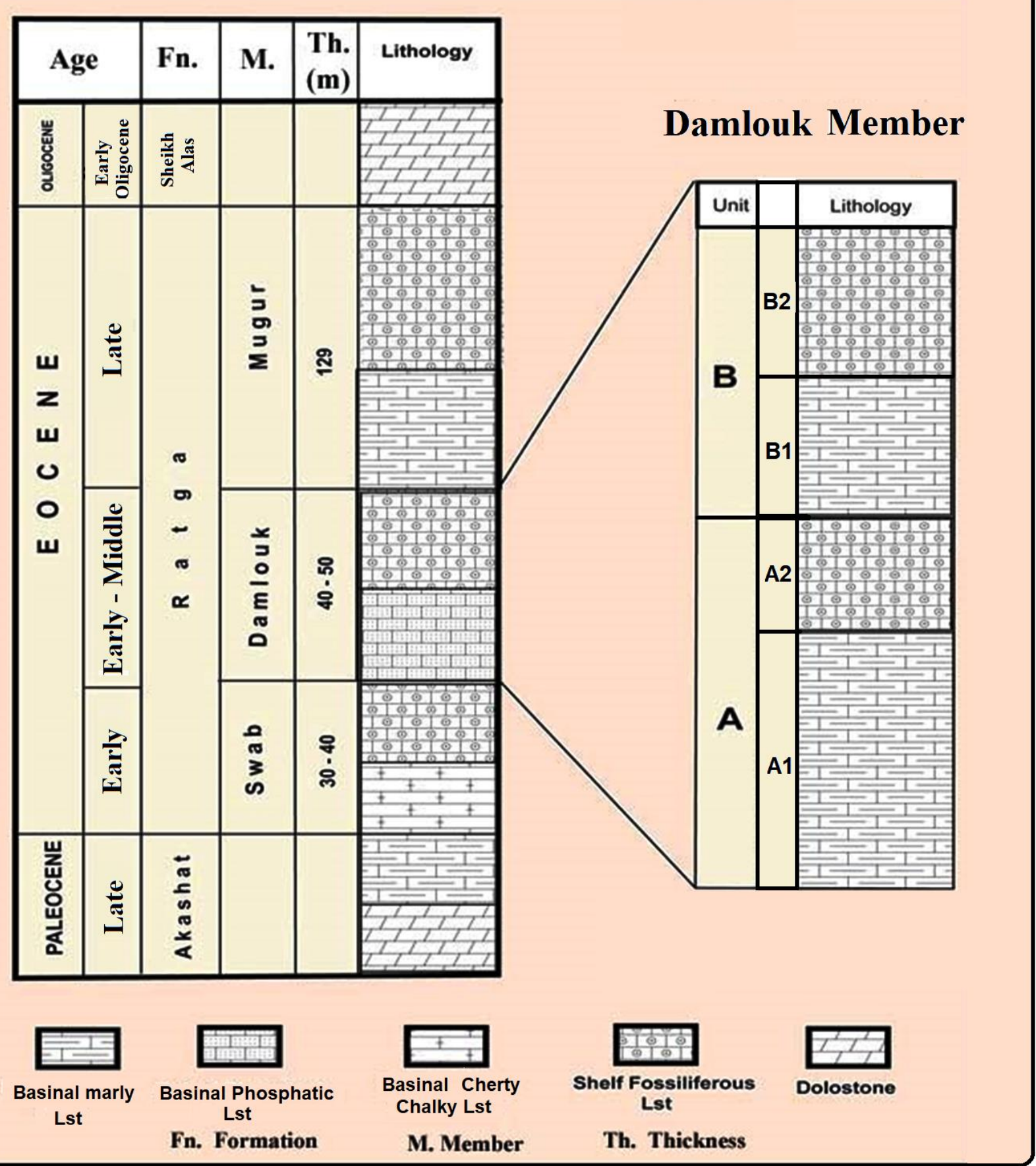

Fig. 2: Stratigraphic column of the Ratga Formation with detailed lithological characters of the Damlouk Member (Based on the description of (Al-Bassam, et al., 1986; and Karim and AlBassam, 1997).

These members display cyclic alternations of similar lithologic units (described above). The Lower boundary is conformable with the Paleocene Akashat Formation. The upper boundary is also conformable with Sheikh Alas/ Shurau Formations of Lower 
Oligocene age (Karim and Al-Bassam, 1997). The Damlouk Member is usually recognized with two distinctive cycles informally called Damlouk (A) for the lower cycle and Damlouk (B) for the upper cycle. The type locality of the Damlouk Member is selected from Wadi Akash for Damlouk (A) (28 m), and Wadi Halgum for Damlouk (B) (52 m) (Jassim et al. 1984; Al-Bassam et al. 1986; and Karim and Al-Bassam, 1997). The selected studied section is 32 meters thick and includes the complete lower cycle (Damlouk A) in addition to the basinal marly limestone part of the upper cycle (Damlouk B). The sampling of this section is focused on the basinal part of the upper cycle (B1) due to its fresh exposure and relatively thick section. The lower cycle (Damlouk A) is 11 meters thick and includes both shallow marine and deep marine sediments (Jassim et al. 1984; Al-Bassam et al., 1986; and Karim and Al-Bassam, 1997). The deep marine unit (A1) is about 9 meters thick and usually consists of phosphatic limestone and chalky limestone (occasionally phosphorite), with occasional silicification (Fig. 3). The phosphatic limestone part of (A1) is becoming marly limestone towards the bottom of the sequence, forming altogether the deep marine part of the cycle. The shallow marine unit of this cycle (A2) consists of 2 meters thick horizon of Nummulitic - shelly limestone. This unit represents part of a shallow marine carbonate bank (Karim and Al-Bassam, 1997; Al-Qayim et al., 2019). This limestone is often hard, protrudes out, and contains abundant and diversified assemblages of Nummulites.

The basinal deep marine sediments of the upper cycle (Damlouk B) are the only representative part of the upper cycle (B1), whereby the upper shallow marine part is removed by recent erosion. The exposed and sampled section of this basinal unit (B1) is 21 meters thick, which is considered relatively the thickest in the area. The lower part of this unit is about 10 meters thick buff relatively soft phosphatic limestone. The upper part of this unit is 11 meters thick and consists of white chalky limestone, which displays silicification in the form of dark brown thin cherty layers or nodules (Fig. 3).

\section{MATERIALS AND METHODOLOGY}

Field description of the studied section includes lithological documentation and stratigraphic relations. Nine samples are collected from the basinal unit of the upper cycles (Damlouk B). Three samples are from the phosphatic limestone part and six samples are from the silicified chalky limestone part (Fig. 3). The samples are collected in uniform spacing and chosen from hard parts to be suitable for thin sections that are made at the workshop of the Department of Geology, Sulaimani University, and examined under Leitz polarizing microscope for identification of the different species of the planktonic foraminifera. Identification and classification of the examined foraminifera are done following the works of (Pearson and Wade, 2015; Loeblich and Tappan, 1988; Loeblich and Tappan, 2015; and Wade et al., 2011). 


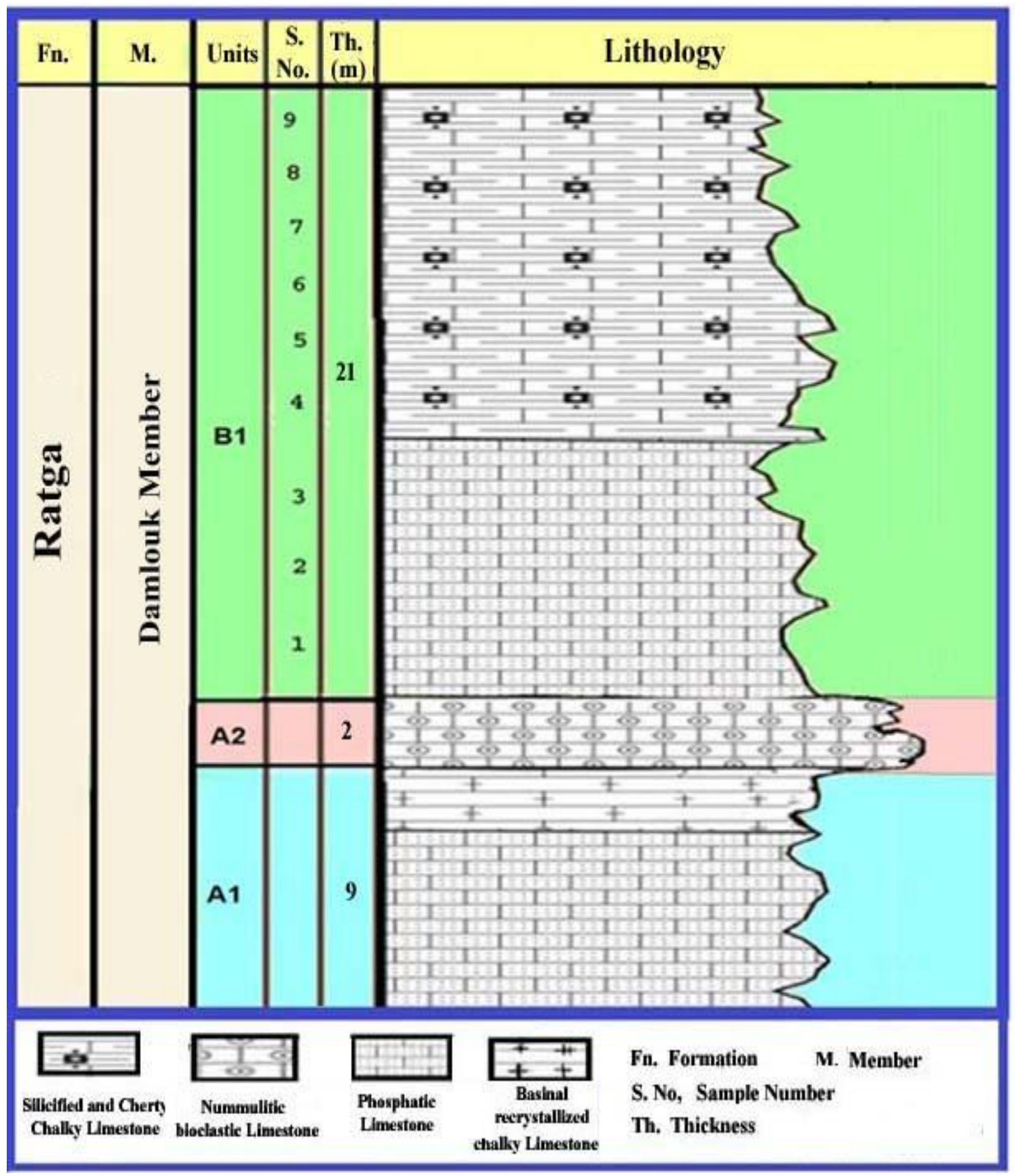

Fig. 3: Lithostratigraphic column of the studied part of the Damlouk Member, Ratga Formation, W. Iraq. 


\section{PLANKTIC FORAMINIFERAL ASSEMBLAGES}

The first description of Eocene planktic foraminifera was made during the nineteenth Century during early geological exploration in Europe (e.g., Gümbel, 1868; Hantken, 1875; Terquem, 1882). This study is based on an analysis of nine samples taken from the studied section that led to the identification of 30 species belonging to the 11 genera of planktic foraminifera, which are distributed from the lower to the upper part of the section. The planktic foraminifera species recognized within the studied section are: (Turborotalia cerroazulensis (Cole); Turborotalia cocoaensis (Cushman); Turborotalia frontosa Subbotina; Turborotalia prolata; Turborotalia pseudoampliapertura Bolli; Turborotalia sp.; Globigerinatheca semiinvoluta (Keijzer) ; Globigerinatheca lutherbacheri Bolli; Globigerinatheca tropicalis (Blow and Banner); Globigerinatheca sp.; Acarinina bullbrooki (Bolli); Acarinina sp.; Catapsydrax dissimilis (Cushman and Bermúdez), Catapsydrax sp.; Globanomalina sp.; Globanomalina planoconica (Subbotina);Hantkenina alabamensis Cushman; Hantkenina liebusi Shokhina; Hantkenina sp.; Chiloguembelina midwayensis (Cushman); Chiloguembelina sp.1 (Cushman and Renz; Chiloguembelina cubensis (Palmer); Chiloguembelina sp.2; Morozovelloides lehneri (Cushman and Jarvis); Morozovelloides coronate (Blow); Morozovelloides sp.; Subbotina eocaenica (Gümb); Subbotina utilisindex (Jenkins and Orr) ; Subbotina gortanii (Borsetti); Orbulinoides sp.)

\section{BIOSTRATIGRAPHY}

The studied section of the Ratga Formation yielded rich planktic foraminiferal assemblages of good preservation. Thirty planktic foraminiferal species belonging to eleven genera had been identified (Fig. 4). These planktic foraminiferal assemblages are typical of tropical subtropical Tethyan character (Berggren and Pearson, 2005). The stratigraphic distribution of the planktic foraminiferal species is shown in Figure (5). The stratigraphic distribution of these planktic foraminifera permits the recognition of three biozones (Fig. 6). These are from the oldest: Acaranina bullbrooki Zone, (Middle Lutetian), Morozovelloides lehneri Zone, (Late Lutetian) Globigerinatheka semiinvoluta-Hantkenina alabamensis Zone (Early Bartonian). These zones are correlated with similar zones which were established by other authors as shown in figures (7and 8). Below is the description of each of these biozones.

\section{1-Acarinina bullbrooki-Total Range Zone}

Definition: Biostratigraphic interval of this zone characterized by the first Appearance Datum (FAD) and Last Appearance Datum (LAD) of Acaranina bullbrooki (Bolli), from the lower to the upper part of the zone.

Thickness: $10 \mathrm{~m}$ represented by the samples $(1-4)$.

Characteristics: It represents the oldest zone recognized in Ratga Formation. The base of this zone represents unit A2 of the Ratga Formation. Planktic foraminiferal assemblages that dominated throughout the zone are: 
Acarinina bullbrooki (Bolli); Acarinina sp.; Chiloguembelina midwayensis (Cushman); Chiloguembelina sp.1; Chiloguembelina cubensis (Palmer); Chiloguembelina sp2; Turborotalia frontosa Subbotina; Subbotina eocaenica (Guembel); Subbotina utilisindex (Jenkins and Orr) ; Subbotina gortanii (Borsetti); Orbulinoides sp.; Turborotalia sp.

Remarks: This zone was recorded from Late Lutetian (Late Middle Eocene) by (Karim and Kubaysi 2015; Popov et al. 2019).

Correlation: This zone is correlatable with the Globigerinatheka subconglobata and Morozovella lehneri (Part) Zone of (Bolli, 1966; Premoli Silva and Bolli, 1973), with the Acaranina rotundimarginata -Hantkenina alabamensis zone of (Krashininikov et al., 1985), Acaranina bullbrooki zone of (Popov et al., 2019) (Fig. 7), and correlated with other biostratigraphic subdivisions recognized in Iraq (Fig. 8).

Age: Late Middle Eocene (Middle Lutetian) -P11

\section{2-Morozovelloides lehneri Zone Total Range Zone}

Definition: Biostratigraphic interval of this zone is characterized by the first Appearance Datum (FAD) and Last Appearance Datum (LAD) of Morozovelloides lehneri (Cushman and Jarvis) from the lower to the upper part of the zone.

Thickness: $5 \mathrm{~m}$ represented by the samples $(4-7)$.

Characteristics: This biozone is recognized at the middle part of the section and characterized by the abundance of planktic foraminifera including Morozovelloides lehneri (Cushman and Jarvis). This biozone starts from sample number 4 and ends in sample number 7. It is characterized by $5 \mathrm{~m}$ thick of Ratga Formation. The common taxa of this zone are represented by (Turborotalia cerroazulensis (Cole); Turborotalia cocoaensis (Cushman); Turborotalia frontosa Subbotina; Turborotalia prolata; Turborotalia sp.; Globigerinatheka semiinvoluta (Keijzer); Globigerinatheka luterbacheri Bolli; Globigerinatheka tropicalis (Blow and Banner); Globigerinatheka sp.; Morozovelloides lehneri (Cushman and Jarvis); Morozovelloides coronate (Blow); Morozovelloides sp.; Subbotina eocaenica (Gümb); Subbotina utilisindex (Jenkins and Orr); Subbotina gortanii (Jenkins and Orr); Orbulinoides sp.

Remarks: This zone was recorded from Middle Lutetian by (Bolli, 1963; Premoli silva and Bolli, 1973; and Bergreen and Pearson, 2015).

Correlation: This zone is correlatable with the Globorotalia lehneri (part)- Orbulinoides bekhmanni zone of Blow 1979, and to the Globigerinatheka ltukemenica zone of Krashininikov et al. 1985, Hantkenina alabamensis zone of Popov et al. 2019 (Fig. 7) and correlated with biostratigraphic subdivisions recognized in Iraq (Fig. 8).

Age: Late Middle Eocene (Late Lutetian)-P 12, P13 
57 Planktic Foraminiferal Biostratigraphy of the Upper Part of the Damlouk Member

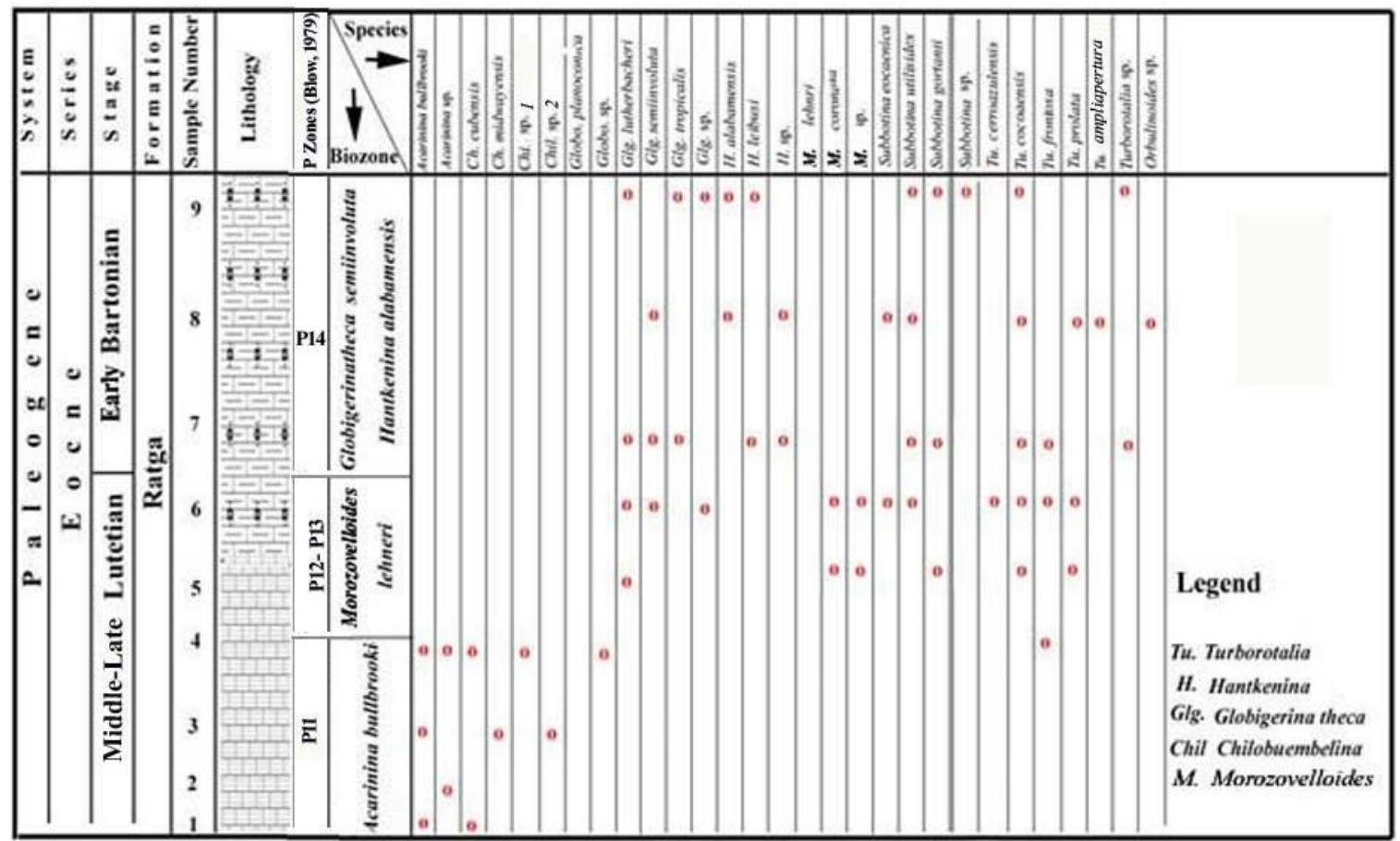

Fig. 4: Biostratigraphic chart of the studied section of the Ratga Formation, Western Desert, Iraq.

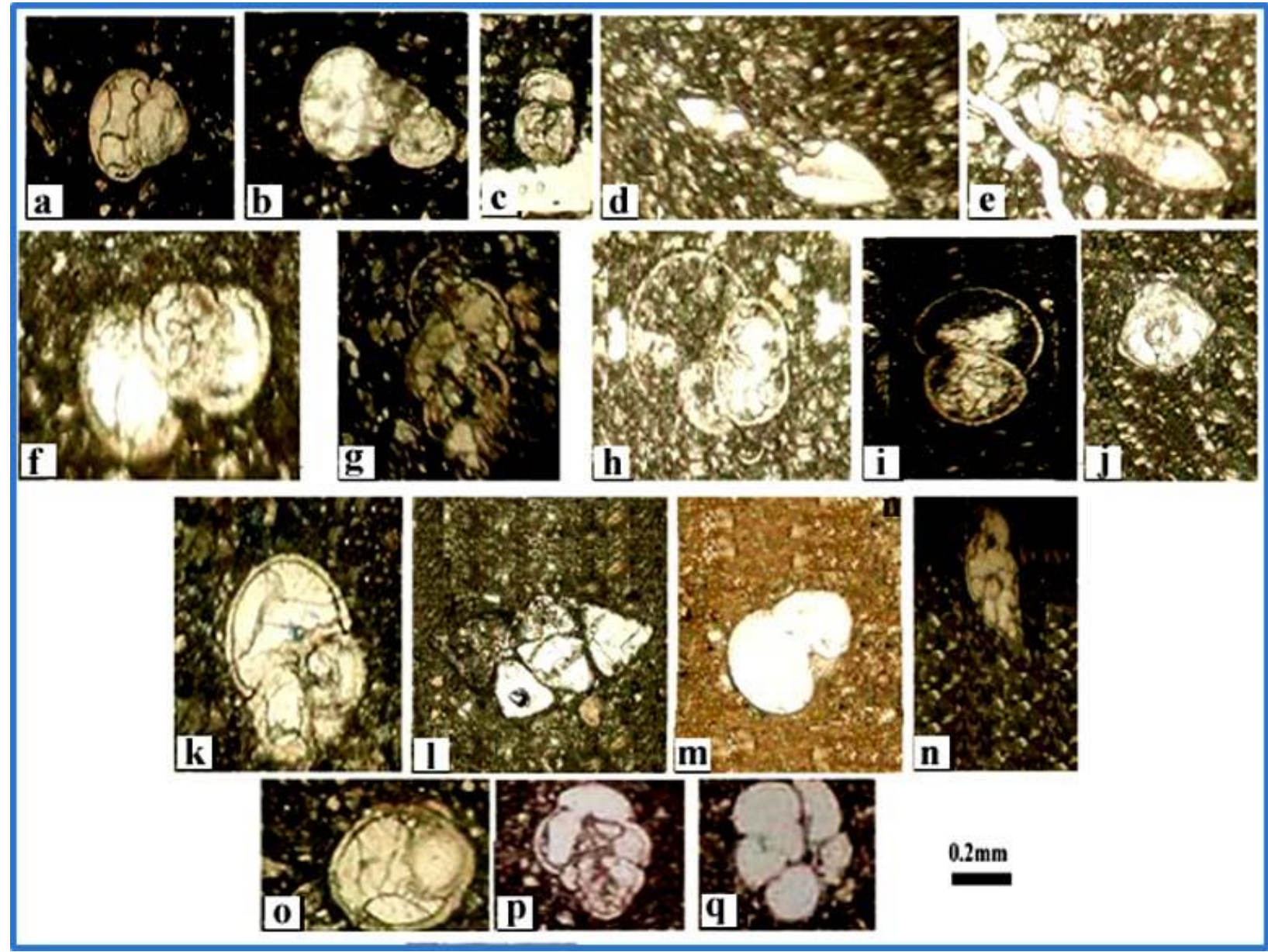


Fig. 5: a. Turborotalia frontosa Subbotina 1953, sample no. 4); b. Globigerinatheka semiinvoluta (Keijzer 1945), sample no. 8); c. Acarinina bullbrooki (Bolli, 1957) sample no. 4; d. Globanomalina sp. sample no. 4; e. Hantkenina alabamensis (Cushman, 1924) (Sample No. 9); f. Subbotina eocaena (Gümbel, 1868), sample no. 8; g. Chiloguembelina sp.2, sample no. 4; h. Turborotalia frontosa Subbotina 1953, sample no.. 6; i. Globigerinatheka tropicalis (Blow and Banner, 1962), sample no. 9; j. Morozovelloides lehneri (Cushman and Jarvis 1929), sample no..5); k. Subbotina utilisindex (Jenkins and Orr 1973), sample no. 9); l. Morozovelloides sp., sample no. 5; m. Morozovelloides sp., sample no. 5 ); n. Chilogumbelina cubensis, (Palmer 1934), sample no. 4); o. Orbulinoides sp., sample no.8; p. Chiloguembelina sp.1; sample no. 3; q. Subbotina sp., sample no. 9.

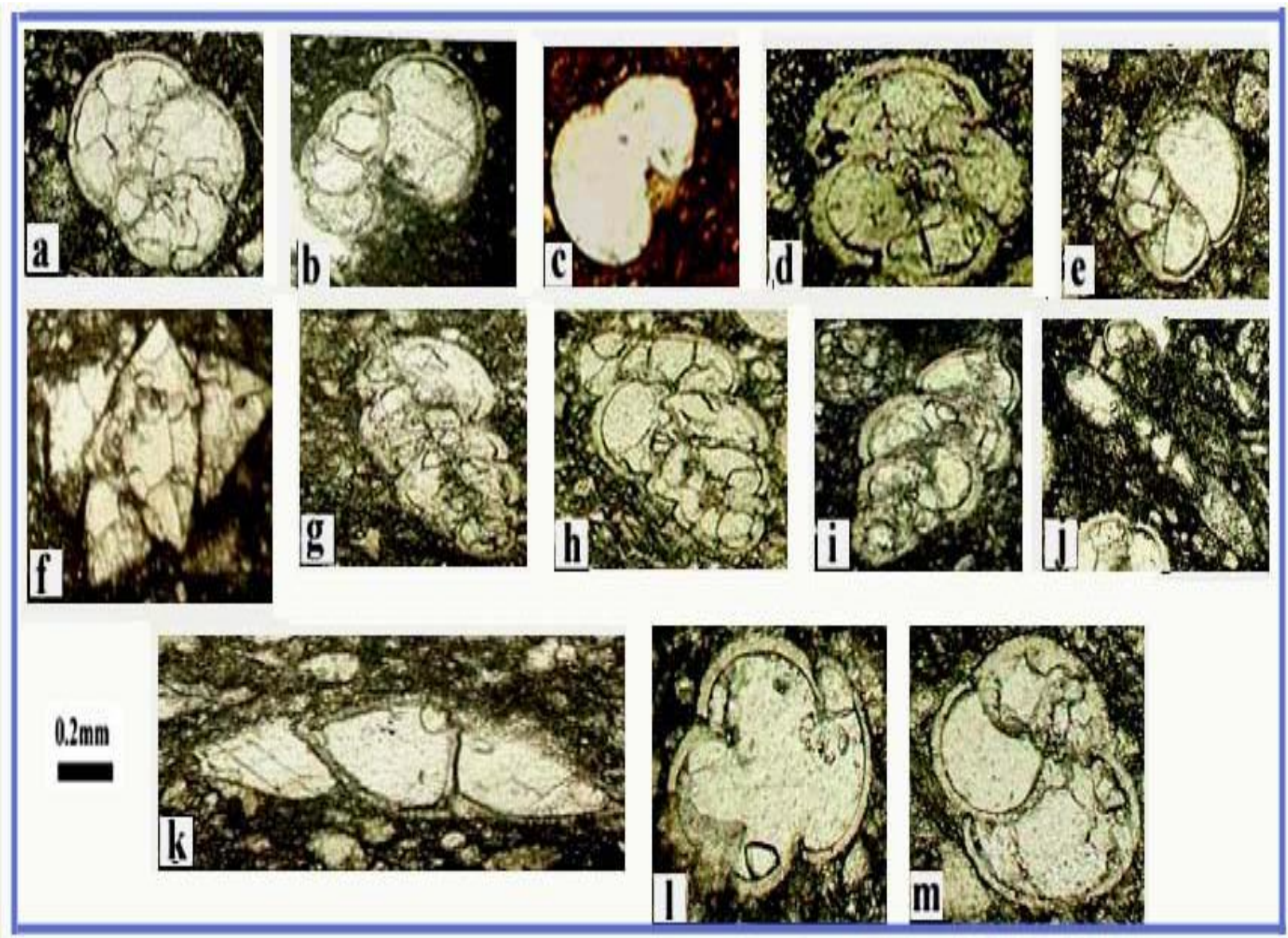

Fig. 6: a. Turborotalia cocoaensis (Cushman, 1928), sample no. 9; b. Turborotalia cerroazulensis (Cole, 1928), sample no. 6; c. Turborotalia prolata Blow, 1979, sample no. 8; d. Globigerinatheka luterbacheri Bolli, 1972, sample no. 9; e. Subbotina gortanii (Borsetti, 1959), sample no. 5; f. Hantkenina liebusi Shokhina, 1937, Sample no. 9; g- Chiloguembelina midwayensis (Cushman, 1940), sample no. 3; h. Chiloguembelina trinitatensis (Cushman and Renz, 1942), sample no. 4; iChiloguembelina sp.1, sample no.4; j. Hantkenina liebusi (Shokhina, 1937), sample nol.3; k. Acarinina bullbrooki (Bolli, 1957) sample no. 4; l. Globanomalina planoconica (Subbotina, 1953), sample nol.3; m. Globigerinatheka semiinvoluta (Keijzer, 1945), sample no 6. 


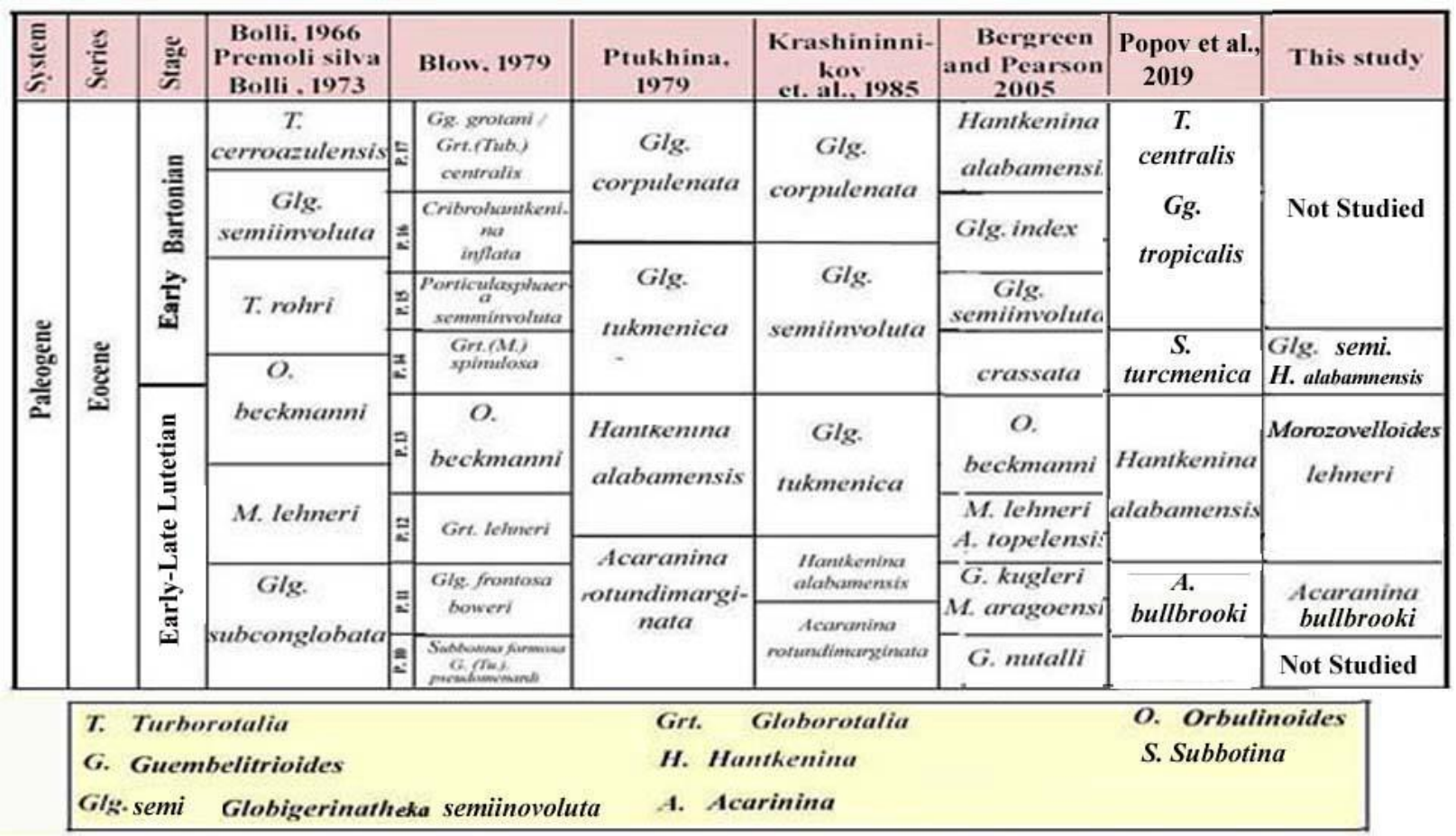

Fig. 7: Correlation of the zonal scheme of part of the Ratga Formation, with other biostratigraphic zones, established outside Iraq.

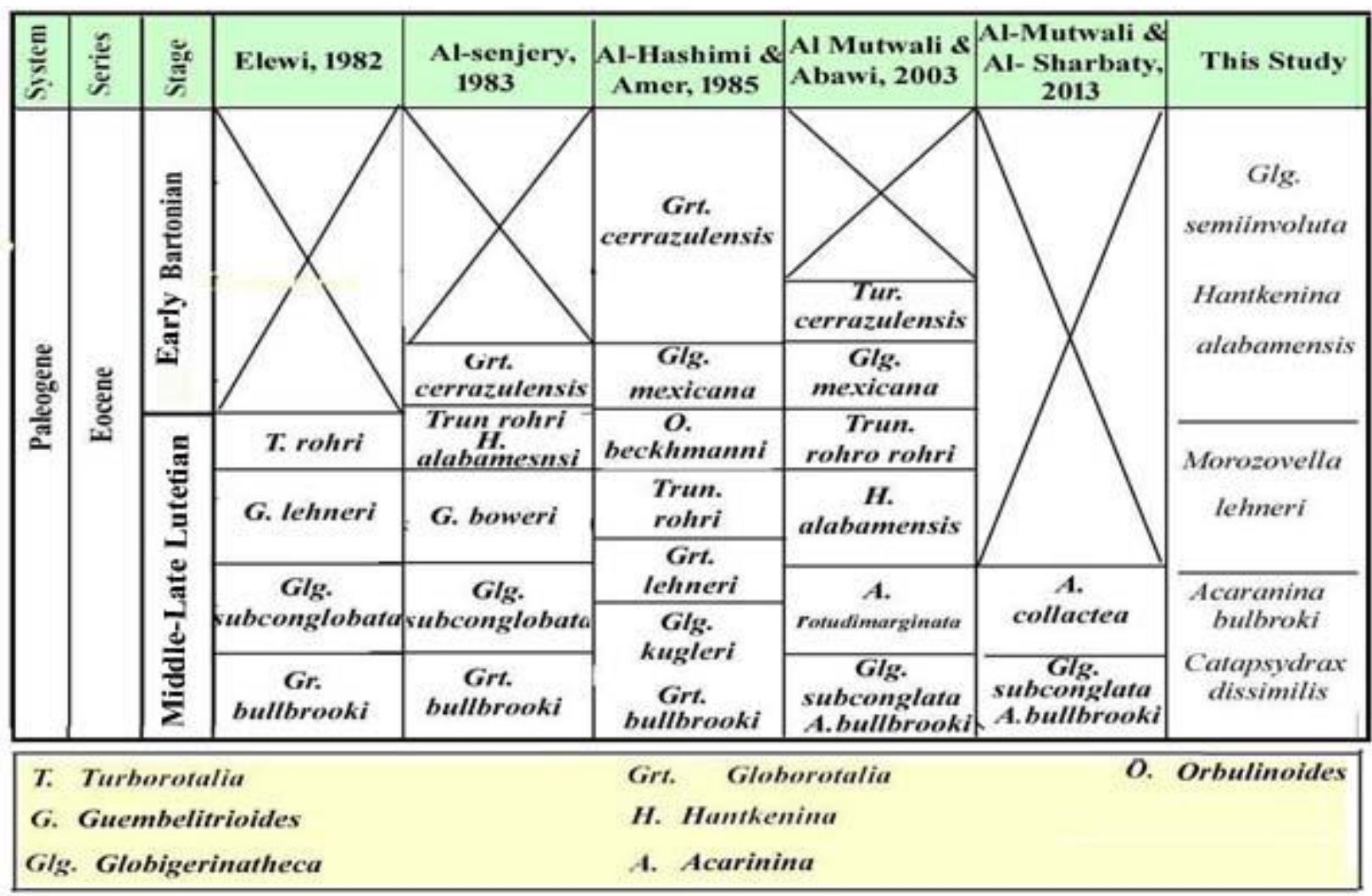

Fig. 8: Correlation of the zonal scheme of part of the Ratga Formation, with other biostratigraphic zones, established inside Iraq. 


\section{3-Globigerinatheka semiinvoluta; -Hantkenina alabamensis Assemblages Zone}

Definition: Biostratigraphic interval of this zone characterized by the assemblage of the nominate taxa Globigerinatheka semiinvoluta (Keijzer) -Hantkenina alabamensis Cushman.

Thickness: $6 \mathrm{~m}$ represented by the samples $(7-9)$.

Characteristics: It represents the zone recognized at the upper part of the studied section. Planktonic foraminiferal assemblages that dominated throughout the zone are:

(Turborotalia cerroazulensis (Cole); Turborotalia cocoaensis (Cushman); Turborotalia frontosa Subbotina; Turborotalia prolata; Turborotalia ampliapertura; Turborotalia sp.; Globigerinatheka semiinvoluta (Keijzer); Globigerinatheka luterbacheri Bolli; Globigerinatheka tropicalis; Globigerinatheka sp.; Globanomalina sp.; Globanomalina planoconica (Subbotina); Hantkenina alabamensis Cushman; Hantkenina liebusi Shokhina; Hantkenina sp.; Chiloguembelina midwayensis (Cushman); Chiloguembelina trinitatensis (Cushman and Renz); Chiloguembelina cubensis (Palmer); Chiloguembelina sp.; Subbotina eocaenica (Gümb); Subbotina utilisindex (Jenkins and Orr); Subbotina gortanii (Jenkins and Orr).

Remarks: This zone was recorded from the early most Bartonian zone p.19 (Early Late Eocene) by (Premoli Silva et. al., 2002; Karim and Kubaysi, 2015; Bolii, 1966; Bergreen and Pearson, 2015; Krashininikov et.al., 1985).

Correlation: This zone is correlatable with the Globigerinatheka semiinvolutaHantkenina alabamensi Globigerinatheka index zone of (Bergreen and Pearson, 2015), (Fig. 7), Subbotina turcmenica zone of (Popov, et al., 2019) and correlated with other subdivisions in Iraq (Fig. 8).

Age: Early Late Eocene (Early Bartonian) - P14

\section{CONCLUSIONS}

This study has the following conclusions:

1-The basinal part of the upper cycle of the Damlouk Member of Ratga Formation in the studied section is characterized by abundant planktonic foraminiferal assemblages.

2. Based on the proposed stratigraphic range of the identified planktonic foraminifera, the section is subdivided into three biozones Acarinina bullbrooki Zone, (Middle Lutetian), Morozovelloides lehneri Zone, (Late Lutetian), and Globigerinatheka similiuluta - Hantkenina alabamensis Zone,( Early Bartonian).

3. This basinal part of the upper cycle (Damluk B) of the Damlouk Member of the Ratga Formation extends in age from the Middle-Late Lutetian to Bartonian. 
61 Planktic Foraminiferal Biostratigraphy of the Upper Part of the Damlouk Member.

\section{REFERENCES}

Al-Bassam, K., Hassim, S., Karim, S. and Mahmoud, K., 1986. Phosphorite project, Annual Stage Report. Geosurv Iraq Library, Intern. Report, 56p

Al-Hashimi, H. A. and Amer R. M., 1985. Tertiary Microfacies of Iraq. State Org. Min. Direct. Gene. Geol. Surv. Min. Investig. Baghdad, 56 p., 159 pls

Al-Mubarak, M. and Amin, R. M., 1983. Report on the regional geological mapping of the eastern part of the Western Desert and western part of the Southern Desert. GEOSURV int. rep. no. 1380.

Al-Mutwali, M. and Abawi, T., 2003. Planktonic Foraminifera and Biostratigraphy of the Jaddala Formation (Eocene), Western Iraq. Iraqi, Jour. of Earth Sci. V.3, No. 1, p67-86.

Al-Mutwali, M. and Al-Sharbaty, S., 2013. Biostratigraphy of Planktonic Foraminifera of Jaddala Formation, (Eocene), Bara area, Northwestern Iraq. Iraqi National Journal of Earth Sciences, Vol.3 No. 2, p. $67-84$.

Al-Naqib, K., 1967. Geology of Arabian Peninsula-Southern Iraq. USGS Prof. Paper, No $560,118 \mathrm{p}$

Al-Qayim, B., Al-Rawi, A., and Al- Bassam, K., 2019. Facies Modeling and Sequence Stratigraphy of an Eocene Carbonate - Phosphorite Ramp: Damlouk Member, Ratga Formation, Western Desert, Iraq. Bulletin of Geology and Mining, Baghdad. V. 15, No. 1, 15-30.

Al-Senjery, A., 1983. Foraminiferal Biostratigraphy of Jaddala Formation in Sinjar Area, Unpublish Ph.D. Dissertation, Baghdad University Library, 178p

Bellen, R., Dunnington, H., Wetzel, R. and Morton, D., 1959. Lexique Stratigraphique, International. International Stratigraphic Commission, Asie, Iraq, Fasc, 10a, Paris, $334 \mathrm{p}$

Berggren, W. A. and Pearson, P., 2005. A revised Tropical to Subtropical Planktonic Foraminiferal Zonation of the Eocene and Oligocene: Journal of Foraminiferal Research, V. 35: p279 - 298

Blow, W. H., 1979. The Cainozoic Globigerinida: E. J. Brill, Leiden, 1413p

Bolli, H., 1966. Zonation of Cretaceous to Pliocene Marine Sediment Based on Planktonic Foraminifera. Bol. Inform. Assoc. Venezolana Geol. Min. Pet. in a, 1:p3 - 32.

Elewi, A. H., 1982. Stratigraphical and Paleontological Studies on some Eocene Rocks in Northern Iraq. (Unpublished M.sc. Thesis). Cairo Univ. 197p

Gumbel, C. W., 1868. Beiträge zur Foraminiferenfauna der nordalpinen Eocängebilde: Abhandlungen der K BayerischeAkademie der Wissenschaften, Munchen, v. 10, p. 579-730. 
Hagopian, D., 1979. Regional Geological Mapping of Nahidain-Tinif area. GEOSURVIRAQ, Int. Rep. No. 983.

Hantken, M., 1875. Die Fauna der Clavulina Szaboi Schichten. I. Foraminiferen: Mitteilungen aus dem Jahrbuche derungarischen Geologischen Anstaalt, v. 4, (1881), p. 1-93

Jassim, S., Karim, S., Basi, M., Al-Mubarak, M. and Munir, J., 1984. The final report on the Geological Survey of Iraq. Geosurv Iraq library, Inter Rep. V. 3, Stratigraphy, $552 \mathrm{p}$

Karim, K., and Al-Bassam K., 1997. The Ratga Formation: A new name for the Eocene Lithostratigraphic Units in the Western Desert of Iraq. Iraqi Geological Journal, V. 30, No 1, 46-60

Krasheninnikov, V.A., 1965. Zonal Stratigraphy of the Paleogene in the Eastern Mediterranian. Academy Nauk SSSR Geol. Inst. Trudy, V. 133, pp. 1-76

Loeblich, Jr. AR. and Tappan, H., 1988. Foraminiferal genera and their classification, Van Nostrand Reinhold. 305p.

Loeblich, Jr, AR. and Tappan, H., 2015. Foraminiferal genera and their classification, Springer.445p

PremoliSilva, I., Bolli, H. M., 1973. Late Cretaceous to Eocene Planktonic Foraminifera and Stratigraphy of Leg 15 Sites in the Caribbean Sea in N. Edgar, J. Saunders, et al., Initial Rep. Deep Sea Drill. Proj., Vol. 15, pp. 449 - 547

Pearson, P. and Wade, B., 2015. Systematic taxonomy of exceptionally well-preserved planktonic foraminifera from the Eocene/Oligocene boundary of Tanzania, Cushman Foundation for Foraminiferal Research Special Publication V. 45(45): 185 .

Popova, S. V., Tabachnikovab, I. P., Pinchukc, T. N., Akhmetievd, M. A., and Zaporozhetsd, N. I., 2019. The Reference Section of Eocene Deposits in the Belaya River Valley, Adygea, Western Ciscaucasia, Stratigraphy and Geological Correlation, Vol. 27, No. 1, pp. 118-132.

Ptukhian, A. E., 1979. Distribution nummulites in Paleogene sediments of YerevanOrdubad structural facies zone. Izv. of AS ASSR, Earth Sciences V. 32, No. 3.

Terquem, O., 1882. Les Foraminifères de l'Eocene des Environsde Paris: Mémoires de la Société Géologique de France, ser.3, v. 2, Mém. 3, p. 1-193

Wade, B. S., Pearson, P. N., Berggren, W. A. and Pälike, H., 2011. Review and revision of Cenozoic tropical planktonic foraminiferal biostratigraphy and calibration to the geomagnetic polarity and astronomical time scale, Earth-Science Reviews V. 104: 111-142. 